\title{
The Militarisation of South African White Society, 1948-1990
}

\section{McGill Alexander}

\section{Introduction}

The extent to which white South Africans were subjected to enforced militarisation, and indeed acquiesced to it, during the second half of the twentieth century could be seen, at least in part, as contributing to the apparent reluctance of some whites to commit themselves to the democratising process in the country.

In this paper the laying of the foundations for militarisation are outlined, the subsequent growth of this militarisation is examined and its possible effect on the transformation currently taking place in South Africa is indicated.

In doing so, the political actions of the National Party are considered, insofar as they succeeded in legislating military obligations on the white populace and utilising the Defence Force as a vehicle to impose the Afrikaner culture on all sectors of white society. This is seen in the context of growing black nationalist resistance and the international isolation of South Africa. The impact on white society of an increasing military burden and of direct involvement in repression of black resistance is considered as having a braking effect on the subsequent commitment by some whites to the democratising process in South Africa.

\section{The Post-War Ambience in South Africa}

At the end of the Second World War the white population of South Africa found itself in a polarised position which ostensibly was not in the least conducive to militarisation. The wartime supporters of the United Party coalition had come through six harrowing years of the war effort. Long absences from home, exposure to debilitating combat, suffering the rigours of prisoner-of-war camps, excruciating boredom between campaigns and lost time and opportunities for acquiring jobs and advancing careers had caused most returning soldiers to shy away from any further military activity or commitment. The war, after all, was over and it was now time to establish oneself as a civilian. This in itself was difficult enough for the restless returned soldiers. ${ }^{1}$ Similarly, wives and sweethearts as well as mothers had had enough of the hardships of a war economy and taking the place of the man. No one in this group would have appeared as likely targets for the militarisation of civil society. 
Those whites who had been opposed to the war, on the other hand, still harboured deep feelings of resentment towards the Union Defence Force and all that it represented. Throughout the war the soldiers in uniform had epitomised Smuts's perceived subservience to the British and South Africa's participation in "Britain's war".2 As such they had long been the target of emotional supporters of the anti-war faction. ${ }^{3}$ This faction wanted nothing to do with a Defence Force which they considered as foreign. Though some of them had been members of right-wing quasi-military organisations such as the Ossewabrandwag and the Greyshirts, they were not open to influence by the Union Defence Force or a government bent on incorporating them into state militarisation.

A third group of whites, who may have felt neutral towards the war, had most certainly been subjected to the inconvenience and imposition of wartime measures. They therefore had little cause to show affection towards the military and would probably have been equally resistant to any attempt to militarise the population.

Yet there were other developments which were to drive all these disparate factions into participation in a programme of militarisation of the white populace probably equalled in South Africa's history only during the wars on the Eastern Frontier of the Cape Colony in the $18^{\text {th }}$ and $19^{\text {th }}$ Centuries. ${ }^{4}$ The first such development was undoubtedly the National Party victory at the polls in 1948. This brought about an overnight and radical change to the South African government's view of its position on the world stage and its attitude towards the black voteless majority living inside the country.

The swart gevaar and swart oorstroming tactics on which the National Party had largely based its campaign for white votes during the run-up to the election ${ }^{5}$ now occupied most of the new government's attention. During the decade following the election the new government systematically legislated its policy of apartheid in an effort to secure and entrench white dominance in South Africa. ${ }^{6}$ This programme of institutionalised segregation went hand in hand with a not-always-subtle propaganda campaign aimed at ensuring that white voters would become almost paranoically alarmed at the threat posed to their way of life by the disenfranchised black majority. Separation of the races was advocated as the only solution and the Prime Minister, Dr DF Malan, argued that: "We have the choice of giving the whites theirown territory and the Bantu theirs, or

FA van Jaarsveld, From Van Riebeeck to Vorster 1652 - 1974 (Johannesburg, Perskor, 1975), p 248.

BJ Liebenberg and SP Spies (eds), South Africa in the $20^{\text {th }}$ Century, (Pretoria, JL van Schaik, 1993), p 285.

ME Katzen, "Frontier Wars (1779 - 1878)", Standard Encyclopaedia of Southern Africa, Vol. 5 (Cape Town, Nasou Ltd., 1972), pp 55-61.

Prof CFJ Muller, Five Hundred Years - A History of South Africa (Pretoria, Academica, 1973), pp 384-387. 
of giving everybody one state and seeing the Bantu govern."7

Incidents of black resistance to the imposition of apartheid, such as the defiance campaign of $1952,{ }^{8}$ boycotts, stay-aways and big strikes like the one at the Amato textile factory on the East Rand, were seen as justifying the fears of the whites. ${ }^{9}$

At the same time, the ardour of black nationalism elsewhere in Africa in the wake of the Second World War, was beginning to touch the borders of South Africa. ${ }^{10}$ The "wind of change" spoken of by Harold Macmillan, British Prime Minister, when he addressed both houses of South Africa's parliament in 1960, was being felt as it blew across the country from the north. ${ }^{11}$ This wind sent a chill of fear rippling through the white population, and the National Party government, in its fervour to gain unified white support for its segregationist policy, was quick to exploit the situation by stressing and highlighting the negative, anti-white issues and atrocities associated with the stirring that was afoot in Africa.

The killing of white settlers in Kenya by the Mau Mau in the early $1950 \mathrm{~s}^{12}$ presaged the chaos and bloodshed in the Congo after its rushed independence from Belgium in $1960^{13}$ Elsewhere in Africa the dawning of independence seemed to herald no great promise for the future: Ghana, the pioneer of Pan-Africanism, suffered the first of many coups d'etat within nine years of independence; Nigeria, the potential economic giant of Africa, was embroiled in a crippling civil war within a decade of gaining its independence; Ruanda and Burundi split along tribal lines in a plethora of bloodshed. Unrest and instability characterised many newly independent states. Between 1961 and 1991 there were 80 violent coups in Africa; 23 national leaders had been assassinated or executed while 12 others had been forced to resign or were dismissed from power; by the mid-eighties there were 20 one-party states in Africa and 21 military dictatorships. ${ }^{14}$

Ironically, the very internal problems of the countries of Africa meant that there were relatively few problems in their relations with one another. All the new states of the continent became members of the Organisation of African Unity (OAU), which came into

William Beinart: Twentieth-Century South Africa (Cape Town, Oxford University Press, 1994), p 154.

Liebenberg and Spies, SA in the $20^{\text {h }}$ Century, pp $379-381$.

Beinart, Twentieth-Century SA, p 159.

Monica Wilson and Leonard Thompson (eds), The Oxford History of South Africa, Vol II, South Africa 1870 - 1966 (Oxford, Clarendon Press, 1971), p 422.

JD Fage, A History of Africa (London, Routledge, 1995), p 487.

Fage, A History of Africa, pp 484 - 485.

Ken Smith and FJ Nöthling, North of the Limpopo - Africa Since 1800 (Pretoria, Unisa, 1993), pp 392-437. 
being in 1963 with its headquarters at Addis Ababa. ${ }^{15}$ Yet, to white South Africa, this apparent unity between black African states seemed to pose a dire threat to their bastion that was being created in the south.

It was this perception of threat, both from the downtrodden black majority inside the country and from the antagonistic black states to the north which, more than anything else, created the required climate for the militarisation of white society in South Africa. Differences were quickly forgotten as the new patriotism that was propagated by the government was increasingly embraced by all sectors of the white population. "Western civilisation", as epitomised by white South Africa, was portrayed as the only way to prevent South Africa from slipping into the abysmal chaos of the rest of Africa. To protect this civilisation and to ensure its continued preservation on the continent had become the sacred duty of each young white male citizen of South Africa. So ran the propaganda line of the National Party government. ${ }^{16}$

The National Party victory in 1948, therefore, together with the perceived internal security threat and external animosity, set the stage for the militarisation of white society in South Africa. By deliberately associating this perceived danger with the declared intention of world domination by international communism, the government succeeded in further convincing the majority of whites of the necessity of taking up arms in what was portrayed as the defence of their country. ${ }^{17}$

\section{A New Approach to Defence and the Armed Forces}

Ever since the accession to power of the National Party, South Africa's emphasis on the question of military defence had been undergoing a marked and steady shift. In terms of the shortlived Middle East Defence Organisation (MEDO) agreement, signed in London on 27 June 1951, South Africa was expected to provide an armoured division and nine air force squadrons as part of a Commonwealth contingent for active service in the Middle East should the need arise to counter a Soviet offensive against Africa. It was for this division that South Africa acquired 201 Centurion tanks, as well as Ferret scout cars and Saracen armoured personnel carriers from the United Kingdom in the early fifties. ${ }^{18}$

However, after the MEDO agreement lapsed in 1957, the South African Minister of Defence, FC Erasmus, realised that South Africa would no longer be welcome

Fage, A History of Africa, p 491.

Review of Defence and Armaments Production, 1960-70 (Pretoria, Department of Defence, Apr 1971),p 16.

Anthony Harrigan, Defence Against Total Attack (Cape Town, Nasionale Boekhandel, 1965), pp 88-96; the declared intention at the time of communism to conquer the world is quite graphically set out, with supporting references, in Henry R Pike, A History of Communism in South Africa (Germiston, Christian Mission International of South Africa, 1988), particularly p 550.

Louisa Jooste, FC Erasmus as Minister van Verdediging, 1948 - 1959 (Pretoria, Unisa MA Dissertation, 1995) pp $147-150$ and pp $187-188$. 
in international military alliances, but would instead need to concentrate her efforts on defence of the homeland. South Africa even sold off most of the new Centurion tanks to Switzerland ${ }^{19}$. This viewpoint, however, had not prevented the new government from despatching the country's No. 2 Squadron from the SA Air Force to participate in the Korean War between 1950 and $1953 .^{20}$ This quick response to an appeal by the United Nations was easily understood though, as it entailed fighting the communists.

Nevertheless, by and large South Africa became, after the Second World War, markedly introvert in terms of its defence policy. Examples of this abounded during the fifties. One of the most significant of these was the signing of the Simon's Town Agreement with Great Britain on 30 June 1955, in terms of which South Africa undertook to share the defence of the Cape sea route. It signalled not only the shouldering of South Africa's own responsibility for the seas around the country, but the start of an unprecedented growth in the SA Navy. ${ }^{21}$ This was done not so much in an effort to be a part of the Western World's defence structures as it was a means of decreasing the presence of foreign (British) warships in South African waters and ensuring that South Africa saw to its own maritime defence rather than that of other countries.

There were many other ways in which the Union Defence Force was weaned of the "British" influence by the National Party Government. Most obvious of these was the apparent post-1948 "purge" of senior and general officers who were known and open supporters of the defeated United Party and who held key positions in the armed forces.2 There was also an apparent effort to prevent English-speaking officers from occupying key posts. This was epitomised by the celebrated case of Major-General Evered Poole, internationally acclaimed and highly decorated General Officer Commanding $6^{\text {th }}$ South African Armoured Division in the Italian campaign during the Second World War and Deputy Chief of the General Staff at the time of the National Party election victory in 1948. Poole was the designated successor to Lieutenant-General Sir Pierre van Ryneveld, the Chief of the General Staff, who was due to retire in 10 months' time. Poole's post was scrapped by the new Defence Minister and the talented young general (he was only 46) was bundled off to Germany to take charge of South Africa's relatively unimportant military mission in Berlin. An Afrikaans-speaking general who had seen no active service during the war was appointed to replace Van Ryneveld whilst Poole was seconded to the

Jooste, FC Erasmus, p 149.

Dave Becker, 75 Years on Wings of Eagles (Durban, Colorgraphic, 1995), pp 97 - 98.

A Navy for Three Oceans (Cape Town, BP Southern Africa, 1997), p 11

During an interview with the late Brigadier HJ Bronkhorst (Quartermaster General of the Union Defence Force in the early 1950s) in Cape Town on 8 September 1992 he described how he had been forcibly retired early by the new government and how he subsequently became a United Party Member of Parliament. Philip H Frankel, however, in Pretoria's Praetorians (Cambridge, University Press, 1984), pp. 18 - 19, intimates that such experiences are perhaps over-dramatised and that what happened to the Union Defence Force is not readily comparable with a purge of military ranks and institutions. 
Department of Foreign Affairs to serve abroad as an ambassador until his eventual retirement. ${ }^{23}$ Though understandable that the new government should ensure that the country's Defence Force was not commanded by someone clearly not supportive of them, Poole's international reputation as a result of his outstanding war record made his removal and sidelining an issue which was hotly debated in Parliament and the press. Within the Defence Force, opportunities for promotion for Afrikaners increased greatly, ${ }^{24}$ sending a definite message to English speakers, who began to feel increasingly unwelcome in the regular forces; and it was the regular forces who determined the character of the Defence Force.

It should not, however, be accepted that this effort to "Afrikanerise" the Defence Force was a unique exercise in South African history. A similar situa tion arose when the Smuts government came to power at the start of the Second World War. A concerted effort had been made at the time to ensure that those who supported South Africa's participation in the war were appointed to key positions, often resulting in regular officers being by-passed by political favourites who had joined up only for the duration of hostilities. ${ }^{25}$ The UDF, at the time possessing a decidedly "British" character, imposed on almost exclusive official use of English on the approximately $50 \%$ of its soldiers who were Afrikaans-speaking. ${ }^{26}$

In terms of appearance, the South African Army adopted a distinctive two-tone uniform, breaking with the tradition of wearing a typically British monotone uniform. The Commonwealth star, worn as a badge of rank, was replaced by a five pointed star, the centre of which bore the South African coat of arms. ${ }^{27}$ Each point of the star represented a province of the Union and South West Africa. ${ }^{28}$ Ranks, too, were altered to reflect a "more South African character". During the 1950s and 1960s Lieutenant-Colonels became Commandants, Lieutenants became Field-Cornets and Major- Generals became Combat-Generals, all reflecting a rejection of "British" influence and a return to traditional "Boer" terminology. The term "Commandant" was even imposed on the SA Navy as a

Ivor Wilkens and Hans Strydom, The Super-Afrikaners (Johannesburg, Jonathan Ball, 1978), pp 117 - 119. Poole's remarkable career is accurately summarised by Ian Uys, South African Military Who's Who 1452 - 1992 (Germiston, Fortress, 1992), p. 184.

JD Omer-Cooper, History of Southern Africa (London, James Currey, 1994), p. 195.

Gen C.L. de Wet Du Toit, "Herinneringe van genl Christiaan Ludolph de Wet du Toit, DSO”, Militaria, 10/4, 1980, p. 19.

Albert Grundlingh, "The King's Afrikaners? Enlistment and Ethnic Identity in the Union of South Africa's Defence Force during the Second World War, 1939 - 1945," Journal of African History, Vol 40, 1999, p. 364.

"Defence Force, South African", Standard Encyclopaedia of Southern Africa, Vol 3, p. 614. 
substitute for "Commander" for a time. ${ }^{29}$

Organisationally, the Union Defence Force (UDF) underwent some very significant changes to its training structures. Training was clearly the means whereby a change could be brought about in the thinking of the military, particularly the young soldiers. Within weeks of his appointment as Minister of Defence, Erasmus convened a committee under the chairmanship of Brigadier JD Kriegler to investigate training in the UDF. He instructed the committee to look at specific issues, all of which were subsequently implemented by him. These were : the establishment of a corps or a system for the full time training of white youths; the establishment of a faculty of mfitary science at a university; the optimal use of existing training facilities so that South Africa would no longer be reliant on Britain for advanced military training; and the extension of the school cadet organisation as a basis for further military training. ${ }^{30}$ In retrospect this committee can be seen to have laid the foundations for the subsequent militarisation of white South African society.

As a direct result of the committee's recommendations (which conformed totally to the guidelines given by the Minister), several key training establishments were founded which were to play a crucial role in influencing the thinking of both young career officers as well as citizens undergoing military training. These included the Military Academy (established initially under the auspices of the University of Pretoria in 1950 at the SA Military College in Voortrekkerhoogte, moved to the University of Stellenbosch in 1955 and finally to Saldanha, though remaining under the academic auspices of Stellenbosch, in $1958){ }^{31}$ the Military Gymnasium (later known as the Army Gymnasium) in 1949, the Air Force Gymnasium in 1952 and the Naval and Marine Gymnasium (Later re-designated just the Naval Gymnasium) in $1954 .^{32}$ The three gymnasia were to play a particularly significant role in the subsequent militarisation of white society.

\section{The Introduction of Conscription}

At the time there was no national service system of conscription in South Africa. Even during the two World Wars the UDF had relied upon volunteers. After the Second World War and demobilisation, the various Active Citizen Force regiments were dependent upon the recruitment of volunteers to fill their ranks. Many of these recruits were welltrained veterans of the war who were familiar with all aspects of soldiering. But for those

L. Jooste, "Die Politieke Koerswending van 1948 besorg 'n nuwe identiteit aan die Unieverdedigings ", Militaria, Vol 26 (2), 1996, ppl14-116; Lt Col A.C. Martin, The Durban Light Infantry, Vol II : 1935 - 1960 (Durban, HQ Board DLI, 1969), p. 424.

SANDF Archives, DC Group 2, Box No. 3460, File DC/2539 (Committee of Enquiry: Military Training), Enclosure 22: "Opdrag aan die Komitee van Ondersoek in Verband met Opleidingsaangeleenthede in die UVM", dd 22 October 1948. $5-15$. 
young men who were recruited with no previous military experience, a period of basic training was necessary to teach them the rudiments of military discipline, procedures and drills. A period of 30 days continuous training by the Union Defence Force was all that was provided to meet this need, ${ }^{33}$ followed by a further period of 21 days during each of the subsequent three years. ${ }^{34}$ In 1949 , when it was estimated that 22,000 white youths turned 17 each year, only 5,000 per year were being trained under this system for the Active Citizen Force. ${ }^{35}$

Conscription, however, first reared its head in 1952, when this period of continuous training for recruits during the first year was increased to 42 days and the ballot system provided for under the Defence Act was for the first time in South Africa's history resorted to in order to increase the strength of units. ${ }^{36}$ Though recruiting of volunteers continued, the bulk of citizen soldiers were henceforth drawn by ballot. The system was not unlike the American "draft": every young white man, on reaching the age of 16 had to register with the Defence Force; on leaving school his name would, along with all others, be placed in a pool from which $47,5 \%$ would be drawn or "balloted" for military training. ${ }^{37}$ Those thus selected would then be called up, together with the volunteers, for the initial period of 42 days (six weeks) and given basic military training. They would then be allocated to Active Citizen Force regiments with which they would do compulsory further training of 15 days continuous (unbroken) and eight days non-continuous (broken) duration each year for three subsequent years. Judging by the regimental histories consulted covering this period, there was still sufficient volunteer fervour apparent in the wake of the war to ensure a reasonable sprinkling of men who wanted to be there, but the majority most certainly came from the ballot system.

The Defence Minister, Erasmus, was clearly not satisfied with this rather limited extension of military training. But according to Section 64 of the Defence Act of 1912, a member of the Citizen Force's training was restricted to this system spread across four years and any significant change would require an amendment to the Act. Convinced by the General Staff that the sophistication of modern weaponry required an extended period of initial training in line with the practice of National Service being followed at the time in UK, USA and elsewhere, Erasmus had presented a proposal to cabinet early in 1951. It was for 12 months of continuous training during the first year, followed by two years with an obligation of not more than one week of training during each year.

Erasmus's proposal was rejected by the cabinet on the grounds that it would

Neil Orpen, Prince Alfred's Guard: 1856 - 1966 (Cape Town, Books of Africa, 1967), p. 289.

Jooste, FC Erasmus, p. 122.

Debates of the House of Assembly (Hansard), Vol 68, column 5771, 13 May 1949, Reply by the Minister of Defence.

Reginald Griffiths, First City - A Saga of Service (Port Elizabeth, Cadar, 1987), p. 186. 
demand too much from the country's economy and manpower reserves. The cabinet suggested that he recruit volunteers for 12 months' training, so the Department of Defence embarked on a costly recruiting campaign during the remainder of that year in an effort to obtain 500 such volunteers. It was a miserable failure, with only 78 young men offering their services, a large proportion of whom were totally unsuitable for training. The ready availability of jobs for white youths in the private sector at the time did not make a year of voluntary soldiering seem an attractive proposition.

Again Erasmus made his proposal to the cabinet for 12 months' compulsory training for those balloted. Again it was rejected. Adamant, the Defence Minister made an approach to the Prime Minister, Dr DF Malan, and suggested that a six month period be considered. Still, his request was refused. Eventually the persistent Erasmus succeeded in getting the cabinet to agree to a 90 day period, or three months of initial training. This extended period commenced in January 1954 and provided a considerable advance in the preparedness of the Citizen Force. ${ }^{38}$

\section{The Military Gymnasia}

This system, however, allowed no significant time or opportunity to really influence the thinking of young men or their families and would therefore hardly have contributed to the "militarisation" of a society. The three gymnasia, on the other hand, presented opportunities which presaged the eventual introduction of universal white male conscription and which provided a proving ground for many of the training techniques and programmes which were to form part of National Service.

Minister Erasmus, according to Jooste, ${ }^{39}$ was convinced that military training with physical education as an important component was essential for the mental and physical preparedness ("geestelike en fisieke weerbaarheid") of the (white) youth of South Africa. Hence his very clear guidelines to the Kriegler Committee in this regard. Predictably, the committee recommended the establishment of a joint training centre where recruits for the Army, Air Force and Navy could undergo 12 months' of voluntary service. Section 6 of the Defence Act (as amended in 1922) already made provision for young men who were balloted in the Active Citizen Force to opt for voluntary training of not more than one year rather than to do the laid down four-year period of annual camps, so no change to the Act was necessary.

Early in 1949 Erasmus announced the establishment of the Military Gymnasium at Voortrekkerhoogte in Pretoria. ${ }^{40}$ Aspirant trainees ("kwekelinge") for the Gymnasium would need to conform to the following requirements:

Jooste, FC Erasmus, pp. 122 - 123.

Jooste, FC Erasmus, pp. 112 - 113.

SANDF Archival Group MVEF, Box No. 129, File MV/122/1 Gimnasiums: Militêre Gimnasium, Vol 1, Enclosure 1 ("Memorandum: Establishment of a Military Gymnasium"), undated. 
Male South African citizens of white descent.

Between the ages of 17 and 22 .

Unmarried.

Bilingual (English and Afrikaans)

Medically fit.

Have passed at least standard $7\left(9^{\text {th }}\right.$ Grade $)$ but preferably matric $\left(12^{\text {th }}\right.$ Grade).

The intention was to attract young men who had left school but not yet commenced with tertiary education or a vocation. The first four months of training would be devoted to joint basic training and thereafter trainees would be allowed to continue in the arm of service of their choice. This year of training was seen to have a number of advantages:

- It would give a grounding to selected individuals who may wish to subsequently join the Permanent (Regular) Force.

- $\quad$ Those with the necessary academic qualifications could be admitted to the envisaged Military Academy, enabling them to earn a degree and at the same time qualify as an officer in the Permanent Force.

- Training undergone at the Military Gymnasium would be a strong recommendation for those hoping to follow a career in the South African Railways and Harbours, South African Police and other state departments.

Completion of the year of Gymnasium training would exempt the trainees from the four-year Active Citizen Force commitment with its disruptive annual camps.

The first intake of young men for the Military Gymnasium was in January 1950, and Erasmus set in motion a strident recruiting campaign. The National Party gave its wholehearted support, propagating the idea actively amongst the Afrikaner community, while the Afrikaans press enthusiastically encouraged the youth to undertake this privileged duty. $^{41}$

There was some slight concern voiced by the Official Opposition, the United Party, in Parliament, with General Smuts querying the effect that the Gymnasium would have on the Active Citizen Force by depriving it of recruits. The Citizen Force, with its British colonial heritage, had traditionally been pro-United Party, particularly during the Second World War. However, in general there was a fairly ready acceptance of the idea in

$41 \quad$ “."n Plan vir ons Jong Manne”, Die Transvaler, 28 Februarie 1949. 
Parliament. $^{42}$

Erasmus spared no effort nor expense in his advertising campaign. Schools and their cadet detachments, Citizen Force units, radio audiences, newspaper and magazine readers, teachers and vocational information organisations were all targeted by means of visits, pamphlets, advertisements and messages. Although the recruiting campaign was ostensibly directed at all sectors of the white population, it was perhaps understandably the Afrikaner community which supported it wholeheartedly. ${ }^{43}$

Despite the high profile recruiting campaign, the new Military Gymnasium attracted few applicants. It had an authorised strength of 300 trainees, but by the beginning of January 1950 only 48 applicants who conformed to the requirements had been accepted. Training was due to start on 1 February 1950, and it was generally felt within UDF circles that it would be uneconomic to press forward with the idea that year. Erasmus was adamant though, and forced the recruiting to continue. He set high standards for the officers and instructors appointed to the new unit, demanding that the Officer Commanding the Gymnasium ensure that the trainees receive exceptional treatment and training so that they would in turn be recruiting agents when they had completed their year. $^{44}$

Thanks to the concerted efforts of Erasmus, the Military Gymnasium eventually commenced its first year of training with 108 trainees. Though disappointed in the numbers, Erasmus was determined to make a success of the system. In the second year of its existence (1951), the number of voluntary trainees accepted was doubled. By 1952 the Public Service Commission had amended its regulations to allow young men who had completed a year of Gymnasium training to be appointed at one notch higher than the starting salary in the public service. ${ }^{45}$ The benefits of being selected for this training were increasing and the Gymnasium rapidly gained an elite status amongst a certain sector of the community.

The growing popularity of the Military Gymnasium quickly prompted Erasmus to establish the Air Force and Naval Gymnasiums, with the original Military Gymnasium becoming the Army Gymnasium. Each establishment had an authorised strength of 150 trainees, but by 1953 Erasmus had lifted this restriction on numbers. By 1956 the Army Gymnasium had 304 trainees, the Air Force Gymnasium 514 and the Naval Gymnasium 153. Whereas the initial 1950 intake had contained only 30 matriculants out of the total of

Hansard, Vol 68, columns 5758, 5759, 5764, 5770, 5771, 5775 and 5778, 13 May 1949. Jooste, FC Erasmus, p. 114.

SANDF Archives, Group AG (1), box no. 44, File AG(1) 84/116 (Military Gymnasium), Enclosure 5, Circular no. 122 from the Acting Adjutant General to the Officer Commanding the Military Gymnasium, dd 2 December 1949.

SANDF Archives, Group KG, File HGS/AP/VOL/2/1 (Personeel en Algemene Administrasie: Vrywillige Voltydse Diens) Vol 1, Enclosure 2, from the Adjutant General to the Chief of the General Staff, dd 15 February 1952. 
108 , the total of 971 trainees at all three gymnasia in 1956 included 567 matriculants. ${ }^{46} \mathrm{~A}$ year of voluntary gymnasium training appeared to be gaining in popularity amongst the better-educated white youths.

An interesting phenomenon was becoming apparent though, and this showed up particularly in the comparatively low numbers applying for the Naval Gymnasium, and the high numbers for the Air Force Gymnasium. The South African Navy and its predecessors had always maintained very close links with the British Royal Navy and its personnel had in the main been English-speaking.

Amongst Afrikaners there was no real sea-going tradition, so it was perhaps not unexpected that relatively few Afrikaans-speaking youths applied for admission to the Naval Gymnasium. The prospect of spending a year in the navy was, on the other hand, not unappealing to a young English-speaker, especially if it meant being absolved of any commitment to annual "army camps". As the English-speaking community did not wholeheartedly embrace the gymnasium concept this probably explains the relatively small numbers trained by the Naval Gymnasium.

The Air Force made a decision that aspirant pilots would only be selected from amongst Gymnasium trainees. Many youths, from both the Afrikaans and the Englishspeaking communities dreamed of becoming pilots, especially after South Africa acquired its first jet fighters in 1950. ${ }^{47}$ Even if it was not their intention to make the Air Force a permanent career, qualifying as a military pilot could be the first step to becoming a civilian airline pilot and it provided a few years of adventure into the deal. It was therefore not surprising that the Air Force Gymnasium attracted the largest number of trainees.

The Army Gymnasium always appealed to a majority of Afrikaans-speaking volunteers; certainly far more that it did English-speakers. ${ }^{48}$ Though the total numbers which passed through the three gymnasia in the fifties and early sixties were relatively small, because the individuals were selected many of them were destined to exercise influence in their communities in later years. Certainly several of them later to became National Party cabinet ministers. ${ }^{49}$ During this time the gymnasia soon became the prime recruiting ground for officers of the Permanent Force, many of whom went on to achieve general or flag officer rank in the SADF.

SANDF Archival Group MVEF, Box No. 105, File MV/9 "Verslag van die Departementele Komitee insake Weermaggimnasiums", undated.

Herman Potgieter and Willem Steenkamp, Aircraft of the South African Air Force (Cape Town, C Struik, 1980), p. 156.

For example, the eighty matric pupils at a well-known English-Language boys' school in Potchefstroom in 1964 provided six recruits for the Air Force Gymnasium, three for the Naval Gymnasium and only one for the Army Gymnasium (The Mooi, annual magazine of the High School for Boys, Potchefstroom, 1965, p. 31).

Both Roelf Meyer, who held several cabinet posts, and Wynand Breytenbach who was Deputy Minister of Defence, were former Air Force Gymnasium trainees. 
The vast majority of gymnasium trainees, however, merely returned to civilian life after a year of having been inculcated with military discipline and subjected to theories of the white man's anointed role in South Africa. Lectures presented to the trainees served to direct or reinforce their thinking along these lines. Yet the numbers being influenced, in terms of the total white population, were very small indeed. Nevertheless, the contribution of the gymnasia lay in the seminal role they played in framing the later national service system, and the influence they had on later leaders in both the military and civilian sector.

\section{The Military Academy}

The absence of a military academy for the training of young officers in the Union Defence Force had long been an apparent shortcoming. Since its inception the UDF had relied largely on the Military College to fulfill this role. However, the College was a multi-disciplinary establishment that was better suited to providing more advanced weapons, tactical and staff duties training. South Africa did not have an equivalent of Britain's Sandhurst or America's West Point.

Erasmus clearly saw political advantages in establishing a military academy and was quick to initiate the investigation of its feasibility. It seems that from the start the proposed Military Academy was seen as presenting only tertiary academic training, the Military College presumably continuing with the tactical and technical military training of young cadet officers. The UDF General Staff provided the following advantages of the proposed academic training for the Minister to present to the cabinet in order to obtain their approval: ${ }^{50}$

a. The course to be offered would be in great demand and would facilitate recruiting, ensuring that the best candidates could be selected.

b. It would place the officer on an equal footing with civilian professionals.

c. The scientific knowledge gained would enable the professional officer to master the complex apparatus and weaponry of the future.

d. Military training in South Africa would be placed on the same level as that of other foreign states.

e. Any other training of a military educational nature could be undertaken by the new establishment.

f. With such an establishment at the disposal of the UDF, research into military and related problems could be carried out at little or no extra cost. 
The recommendations were that the new Military Academy should function under an existing university, but forming part of the Military College in Pretoria, as a branch of the College. It was here that Erasmus saw his opportunity to impose Afrikaner culture on the young cadet officers. The university chosen to take ownership of the academic education was the Afrikaans-language University of Pretoria. ${ }^{51}$

The man designated by the General Staff to be the Academy's first dean was Major Gideon Jacobs. ${ }^{52}$ Jacobs had had a brilliant academic career before the war, then went on to attend the Imperial Staff Officers' College in Palestine, was seconded to the Royal Marines and trained as a parachutist and commando before participating in the planning for the D-Day invasion of Europe. He was subsequently transferred to the Far East where, with only four men he was parachuted into Sumatra to await the surrender of 80,000 Japanese troops before taking command of the island for the Allies in 1945. Jacobs was awarded the Order of the British Empire (OBE) and went on to gain an MA and a DPhil (cum laude). ${ }^{53}$

Major Jacobs, however, was a "Smuts man" and therefore quite unacceptable to Erasmus for a post which he saw as crucial to his "Afrikanerisation" programme. His appointment was turned down in favour of a firm Nationalist, Major S.A. Engelbrecht, who was not an academic. Within two years he was replaced by Captain (later Major) M. van Niekerk, ${ }^{54}$ a history teacher who had been commissioned on the strength of possessing an MA Degree, though he had no military experience or background. Jacobs left the UDF to pursue a career as an opposition politician and later a successful academic at an English-language university.

From 1955 the Military Science Faculty transferred to the University of Stellenbosch, which had produced so many prominent Afrikaners. By 1958 it had begun operating from the site at Saldanha which was in the process of being developed into a fully-fledged Military Academy, able to function independently as a military unit, though still under the auspices of the University of Stellenbosch for purposes of the conferring of degrees. ${ }^{55}$ From this time the Academy grew steadily and most certainly contributed substantially to producing more professional and better-rounded officers for the SADF.

However, the Academy always turned out only a very small percentage of the total number of officers, as relatively few were found suitable for and capable of university training. Nevertheless, what was significant was the high percentage of officers who had passed through the Academy amongst those who achieved general and flag officer rank. These included Chiefs of the SADF such as Magnus Malan, Constand Viljoen and Jan

Military Academy 1950-1975, p. 5

Boulter, "Afrikaner Nationalism", p. 445.

G.F. Jacobs, Prelude to the Monsoon (Cape Town, Purnell, 1968), inside back cover.

Military Academy 1950-1975, p. 7

Military Academy 1950-1975, pp 15-21. 
Geldenhuys, all of whom played an important part in the militarisation process, especially Malan in his subsequent position as Minister of Defence. It was the minister and the generals who guided the implementation of the whole system of national service in the SADF.

\section{The Defence Act of 1957 and the Start of the Armed Struggle}

Perhaps the event of greatest import to the militarisation of white society in the fifties, was the passing of the new Defence Act (Act No 44 of 1957). Together with many subsequent amendments, this Act was to empower the government to embark on its escalating programme of militarisation. In terms of the Act, the Union Defence Force was superseded by the South African Defence Force and the latter was now far more clearly defined that its predecessor. The Commandos, formerly merely shooting associations, were now raised in status to the same level as the Citizen Force and became fully integrated into the Defence Force. A new Military Disciplinary Code was introduced to cater for the new terms of service contained in the Act. These terms provided for the military training of aliens resident in South Africa and retained both the ballot system for military training as well as voluntary service in the Citizen Force or the Commandos. Every person domiciled in South Africa was made liable to undergo training as a school cadet between the ages of 12 and 17, and to render service in the South African Defence Force between the ages of 17 and $65 .^{56}$

The timing for the passing of the new Defence Act was fortuitous for the National Party government. Events during the first years of the sixties decade prompted the government to commence with a wider implementation of their programme of militarisation. Already in early 1959 there had been outbreaks of violence in the then Federation of Rhodesia and Nyasaland by disenchanted blacks. ${ }^{57}$ On 21 March 1960 the infamous Sharperville incident took place in the wake of an attack on policemen at Cato Manor in Natal. ${ }^{58}$ To the whites in South Africa it was clear that the simmering pot was beginning to boil, and a growing spirit of fear began to gripthe country's governing elite. The referendum for a republic was doubtless influenced in its outcome by the rising spectre of Black Nationalism and the rejection of South Africa's racial policies by Britian, the Commonwealth and the rest of the world. Many of those who would not normally have supported the National Party, particularly amongst the English-speaking electorate, now voted in favour of the republic. ${ }^{59}$

Act no 44 of 1957, Chapter 1, Section 3(1)(a) and (b); also "Defence Force, South African", Standard Encyclopedia of South Africa, Vol 3, p. 614.

Richard Wood, "The Rhodesian Issue in Historical Perspective - The Demise of Rhodesia," Challenge : Southern Africa within the African Revolutionary Context, edited by Al J. Venter (Gibraltar, Ashanti Publishing, 1989). pp. 363 - 364. 
In December 1960 violence erupted in Eastern Pondoland, a remote and underdeveloped part of the Transkei territory. Tribal murders, factionalism and large-scale unrest resulted in the declaration of a state of emergency in the area and the deployment of an Army battle group, Air Force helicopters and light fixed-wing aircraft. Agitators were hunted down in the forests and mountains and the unrest was systematically quelled by the military force. ${ }^{60}$

This little expedition seemed to reinforce white thinking that the mutinies in the newly independent Congo, the attempted secession of Katanga, the civil war and the massacre of whites in that country were a foretaste of what lay ahead for South Africa if blacks were to gain control of the government. ${ }^{61}$ It was therefore not surprising that the length of initial military service for those white youths balloted in South Africa was extended in 1962 from three months to nine months. ${ }^{62}$ Each year in January, April, July and October an intake of young ballotees would be inducted for their nine months' training. It was still a peacetime army, with the concomitant frustrations and boredom, but in the white population as a whole there was a stiffening resolve to prepare itself for a dark future. There was further evidence that their fears were justified: Poqo (meaning "We stand alone"), an organisation founded in 1961 by supporters of the recently banned PanAfricanist Congress (PAC), commenced a campaign of terror against whites in South Africa in September 1962. There were murders, looting and arson in Paarl and murders in Transkei the following year. ${ }^{63}$

Such internal rumblings in the country increased the growing nervousness of the white population. The simplistic solution for a minority bent on retaining its privileged position, was to increase the degree of forced repression of the dissatisfied majority. The privileged, in such an atmosphere, were ripe for a programme of militarisation.

\section{The Liberation Wars of Southern Africa}

In the rest of Africa, too, violence was on the increase. The struggle for Algeria and the flight of the pieds noirs to France, ${ }^{64}$ the continued political upheavel and massacres in Congo ${ }^{65}$ and elsewhere, as well as the anti-white rhetoric which accompanied

SANDF Archives, C Army Group, Box No. 451, Operation SWIVEL (Commander's Diary) and Box No. 575 (Situation Reports : Battle Group Alpha, Operation SWIVEL).

Anthony Mockler, Mercenaries (London, Macdonald, 1970), p. 137; Fage, A History of Africa, pp. 484-485; Smith and Nöthling, North of the Limpopo, pp. 407-408.

"50 Skymen get their Wings", The Friend, 29 January 1962.

Reg Shay and Chris Vermaak, The Silent War (Salisbury, Galaxie Press, 1971), pp 79-88.

Fage, A History of Africa, p.471; "Ben Bella, Ahmed," Encyclopedia Britannica, Macropaedia, Vol 2, p. 834.

Mockler, Mercenaries, pp 155-193; also Hans Germani, White Soldiers in Black Africa (Cape Town, Nasionale Boekhandel, 1967). 
independence in many other former colonies ${ }^{66}$ all added to the feelings of insecurity and alarmism amongst the whites of South Africa. The firm and uncompromising stand on white control adopted by Dr H.F. Verwoerd struck an appealing chord in the anxious hearts of white South Africans.

Closer to home the news tended to further reinforce these sentiments. Portugal's refusal to countenance any notion of independence for its African colonies (euphemistically termed "provinces" by the Portuguese) resulted in the commencement of active insurgency wars of resistance in these vast territories in the early $1960 \mathrm{~s} .{ }^{67}$ Many Portuguese had settled in South Africa, and these wars began to touch the lives of increasing numbers of whites in the country.

Of greater import to white South Africa, however, was the war in Rhodesia. There were deep bonds of kinship between English-speaking South Africans and the Rhodesians. Many family relationships extended across the Limpopo and Rhodesia was a popular tourist destination for South Africans. Rhodesians had fought under command of the UDF during the Second World War ${ }^{68}$ and there were strong ties of imperialist and colonial heritage between those of British descent in both countries. They shared a common culture, a common language and a closely linked history. Furthermore, there were intertwined sporting links, with Rhodesia participating in South African interprovincial competitions and even being represented in South African national teams. Finally, the economy of land-locked Rhodesia was welded to that of South Africa, with most imports and exports passing through South African ports. ${ }^{69}$

South Africans were able to join the Rhodesian armed forces, including the British South Africa Police, without any difficulty or even a change of citizenship. Many English-speaking South Africans with a desire to follow a military career did in fact do this. Those who found the "Afrikanerisation" policies of F.C. Erasmus and other ministers quite distasteful, readily crossed the Limpopo to serve in the Rhodesian forces where they felt more welcome because of the strong British ethos which prevailed there.

Some did this to escape national service in the predominantly Afrikaans SADF (South Africans who had served in the Rhodesian Forces were granted exemption from conscription in the SADF). Others, particularly in the 1950 's, were regular soldiers in the UDF who became disillusioned with the nepotism they perceived as taking place under the guise of what amounted to affirmative action. A subsequent commander of the Rhodesian Army, Lieutenant-General Keith Coster, was a South African who had left the UDF as a

Barnett Potter, The Fault, Black Man.... (Cape Town, Howard Timmins, 1970), pp 130134.

Al J. Venter, Portugal se Oorlog (Cape Town, Human and Rousseau, 1972), pp 18-32

Neil Orpen, Victory in Italy (Cape Town, Purnell, 1975), pp 6 and 16.

A.J. Cottrell, "The Geo-Strategic Importance of Southern Africa", paper in Southern Africa : the politics of raw materials (Pretoria, Foreign Affairs Association), 1977, edited by Cas de Villiers, p. 12. 
major in 1954 to join the Rhodesians. Coster had been staff-trained during the Second World War at the SA Army College and at the British Army Staff College, Camberley, in 1952.70

When Ian Smith's government unilaterally declared independence in November 1965, they enjoyed the sympathy and support of probably the majority of English-speaking white South Africans. Their action and their consequent condemnation by the rest of the world certainly drove many doubters amongst the English-speakers into the Nationalist fold. This is evident from the growing support which the NP gained in the elections during the 1960 s and 1970 s.

In 1967, Prime Minister John Vorster sent contingents of South African Police (surreptitiously beefed up with Army personnel) to assist the Rhodesians in their growing counter-insurgency war. Guerrillas from the Zimbabwean liberation movements were increasing their activities and South Africa's ANC was also active in Rhodesia with elements from MK. ${ }^{71}$ This served to further unite English and Afrikaans-speaking whites in South Africa, as they perceived a common threat to their way of life.

1974 saw the revolution in Portugal, followed by the independence of first Mozambique and then Angola in 1975. The latter's independence took place in the midst of a bloody civil war in which South Africa had become involved. An influx of white Portuguese refugees descended on South Africa with terrifying tales of bloodshed, mayhem and victimisation of whites. ${ }^{72}$ The war in Rhodesia intensified and the SADF became more deeply involved in it. Rhodesian propaganda portrayed the guerrillas as brutal terrorists and graphic photographs of their atrocities committed on innocent civilians were widely distributed. ${ }^{73}$ In South Africa whites felt increasingly beleaguered and a white recourse to arms was seen as the only option to preserve their civilization on the Southern tip of Africa. They were by then extremely vulnerable, even amenable, to militarisation.

\section{National Service and "Border Duty"}

Already in January 1968 the government had introduced a system of universal white male conscription, termed "national service". Consequently, every white household began to get acquainted with life in the military. ${ }^{74}$ With national service had come an extension of the period of initial service to 12 months, while subsequent commitments to

Colonel McGill Alexander, SA Army Staff Training 1927-1996(Pretoria, SADF, 1996), pp 36 and 116.

Michael Morris, Terrorism (Cape Town, Howard Timmins, 1971), pp 40-42. Also Howard Barrell, MK-the ANC's Armed Struggle (London, Penguin, 1990), pp 20-23.

"Angola", Encyclopaedia Britannica 1976 Book of the Year (Chicago, Encyclopedia Britannica, 1976), p. 123; F.J. du T. Spies, Operasie Savannah (Pretoria, SADF, 1989) pp 293-303. 
do annual "camps" steadily grew from three years to eight in the Citizen Force, followed by annual service in the Commandos up to the age of 60 .

The growing involvement of first the police and the Air Force, and later also the Army, in the then South West Africa and Rhodesia, meant that soon national servicemen were being deployed in increasing numbers in these countries. "Border Duty" became a euphemism for any operational deployments and the term was soon in regular and accepted use amongst the white population. ${ }^{75}$ It became a point of pride for young white males to "do their bit on the border".

\section{The Citizen Force and 90-Day Call-Ups}

In the wake of Operation SAVANNAH, (South Africa's involvement in the Angolan Civil War of 1975/76), the part-time Citizen Force units were for the first time called up for 90 -day periods to do operational service. The SADF had realised that it was unable to sustain an extended conventional campaign with existing national service manpower resources. ${ }^{76}$

It was a significant though unplanned development in the militarisation process. Prior to this, the trained Citizen Force had been called on to carry out 14,21 or at the most 28-day continuous training camps. Now, not only were they required to do a three-month stretch annually, but they were actually deployed on operations. No longer was it only the boys who had just completed school who were being sent into action: it was also the husbands and fathers, professional men, artisans, farmers and others playing a pivotal role in the country's economy.

That section of the Defence Force known as "Civic Affairs" (later to become "Communication Operations") played a dominant role in convincing soldiers, particularly the part-time Citizen Force, that their military involvement was crucial to the future of the country. The politicians confirmed this to the broader public, and most newspapers were quick to take up this line. 77

As a further consequence of Operation SAVANNAH, the one year of initial national service had been gradually increased, first on a voluntary and well-remunerated basis, through 18 months, to an eventual full 2 years of compulsory service by $1978 .^{78}$ By this time both Parliament and the white population as a whole had been convinced that this was an essential step. There was little opposition.

Yet it was at about this time that an element of white society who were opposed

Spies, Savannah, p 277. 
to conscription began to show their objections. ${ }^{79}$ There had always been a small number of conscientious objectors whose viewpoints were generally based on their religious beliefs. The SADF did allow non-combatant service as an alternative, but now some refused to don uniform or to be associated at all with the military. Examples of young men being charged, tried and sentenced to lengthy prison terms became increasingly frequent. The establishment of the End Conscription Campaign in 1983 saw growing numbers of young white men evading national service on political grounds and simply because they disagreed with the government's military adventurism. ${ }^{80}$ Doubtless the inconvenience and burden of conscription, as well as a general "war-weariness" after a decade and a half of conflict, also played a role. This was perhaps especially so amongst the English-speaking sector of the white population. They may have identified with the aims of the government, but despite a softening of the "Afrikanerisation" practices, they still did not feel fully welcome in the SADF. Overall, however, the numbers of whites resisting conscription were not significant until the late 1980s. Most simply accepted national service as an inescapable part of life, and some clearly enjoyed the adventure it offered in specialised units like the paratroops, trackers, aquestrians and armour.

Perhaps the clearest example of just how far the militarisation process had gone was Operation REINDEER in May 1978. The airborne assault on Cassinga in southern Angola was carried out by a battalion of paratroops, supported heavily by the SAAF. $80 \%$ of the paratroopers were Citizen Force soldiers, at work in their civilian occupations one week, parachuting into Angola to participate in a six-hour battle against SWAPO guerrillas, Angolan and Cuban tanks and other armoured vehicles the next week, and back at work the third, as if it was all a normal occurrence. ${ }^{81}$ They had been extracted from civilian society for only ten days. White society accepted it as such. Militarisation had indeed reached an advanced stage. Personal involvement in the repression of the liberation struggles in neighbouring countries was now accepted without question.

\section{Those at Home}

In the meantime the government had placed a renewed emphasis on the school cadet system. ${ }^{82}$ A larger part of the Defence Budget was allocated to it, uniforms were

Harald E. Winkler and Laurie Nathan, "Waging Peace : Church Resistance to Militarisation", in Jacklyn Cock and Laurie Nathan (eds), War and Society (Cape Town, David Philip, 1989), p 327.

so Laurie Nathan, “' 'Marching to a different beat' : the history of the End Conscription Campaign", in Cock and Nathan, War and Society, p 308.

81 Call-up instructions received by Staff-Sergeant N.J. Grobler, dated 18 April 1978; C.J. Nöthling, Operasie Reindeer (Pretoria, SADF Documentation Service, 1978); Minutes of a debriefing conference on Operation REINDEER, SANDF Documentation Service, Archival Group CS Ops, File CS Ops/310/4/REINDEER. militarisation of white South African schooling", in Cock and Nathan, War and Society, pp 283-296. 
modernised and inter-school competitions were encouraged. Although restricted to boys as a compulsory school activity, girls were encouraged to participate in drill teams on a voluntary basis, and all scholars underwent "youth preparedness" and other training programmes with a military flavour.

Some provision was also made for girls once they had left school. A year of voluntary military training at the South African Women's College in George was introduced in 1971 for girls who had completed matric. By 1978 the College was admitting 500 applicants annually. ${ }^{83}$

Many older English-speakers, nostalgic for the camaraderie of the Second World War, became increasingly enthusiastic about the military, political differences of the past having faded in the face of the "new threat". National service was now given general support by most English-speaking South Africans. ${ }^{84}$

For the mothers of national servicemen, and other patriotic white women, an organisation known as the Southern Cross Fund came into being. ${ }^{85}$ Women were encouraged to assist with raising funds, preparing gift-packages for soldiers "on the border" and seeing "the boys" off when troop-trains departed for South West Africa. Amongst the national servicemen the packages were referred to as "Dankie Tannie Pakkies". Women baked rusks and knitted comforters, socks and gloves for the soldiers, and children enclosed message cards with words of encouragement in the packages. Many of those at home became involved in programmes reminiscent of those of patriotic civilians in the Second World War. In this manner those who could not serve in the forces were made to feel part of the overall "war effort".

\section{Internal Unrest and the 60-Day Call-Ups}

During the late 1970 s and early 1980 s the SA Army grew phenomenally. Many new units were established and professional soldiers were recruited and trained to supplement the national servicemen. "Ethnic battalions" were raised, and eventually it was no longer necessary to send as many Citizen Force soldiers to South West Africa to deploy on operations. ${ }^{86}$ But a useful precedent had been set, and when internal unrest in South Africa flared in 1984, a start was made on deploying the Citizen Force internally in the townships and rural areas. However, because of the closer proximity, and to lessen the effect on the economy, these call-ups were generally for 60 -day periods. ${ }^{87}$

Paul L. Moorcraft, Africa's Superpower (Johannesburg, Sygma, 1981), p66; Jacklyn Cock, "Manpower and militarisation : women and the SADF", in Cock and Nathan, War and Society, p 61 .

Nathan, "Marching to a different beat", p 309.

Frankel, Pretoria's Praetorians, p 98.

Willem Steenkamp, South Africa's Border War, (Gibraltar, Ashanti, 1989), p 232.

Helmoed-Römer Heitman, South African Armed Forces, (Cape Town, Buffalo Publications, 1990), p 39. 
Militarisation had now reached on extreme point. White South African citizens who were not professional soldiers were being employed to repress the liberation struggle of their fellow-countrymen. It was a situation that technically amounted to civil war.

Again the bizarre phenomenon surfaced of young men, often family men who were stable pillars in their own communities, being whipped out of their secure civilian surroundings and deposited into volatile townships or rural tribal areas where they sometimes witnessed or were involved in shocking violence and brutality. Here they were called upon to either separate warring political factions or to curtail and repress the activities of the angry and frustrated black masses. Cordons and searches, roadblocks and patrols brought them face to face with the horror of poverty in squatter settlements and they found themselves interfering with what should have been intensely private matters.

Confused, these men just as suddenly found themselves back at work as civilians and in their own comfortable homes. Distasteful though they found these periods of operational duty, they had been assured by their government and by their military superiors that what they were doing was absolutely necessary to prevent SA sliding into chaos. Though many may have doubted this, they and their society were sufficiently militarised to simply do what they were told. They had in any case become completely isolated in their own communities from black South African society. For most, the only way to deal with the struggle of those whom they were called on to oppress, was to adopt the detached air of an outsider and to pretend that it was not happening once they got home. Denial may have been one way to handle a mixture of guilt with an awareness of the magnitude of the threat to their way of life. Doubtless for some at least, this regular exposure to "township duty" reinforced or produced a callous and unfeeling attitude towards their black fellow countrymen.

And yet, it would be interesting to investigate the effect of "township duty" on the outcome of the referendum of 1992. Certainly an overwhelming number of young whites voted in favour of a negotiated settlement of South Africa's future. Perhaps working in the townships had opened the eyes of many young white men to the true plight of their fellow South Africans. In this sense, the militarisation process could ultimately and inadvertently have made a positive contribution.

This is perhaps substantiated by the fact that it was during this frenzy of feeding on itself that South Africa saw a growing increase in opposition to conscription. Though the End Conscription Campaign was prevented from being really vociferous, it did surreptitiously assist growing numbers of white males to avoid doing national service and evade annual camps. More and more Citizen Force members simply did not report when called up for annual camps and there was a burgeoning resistance to being employed against black South Africans. The concern of government was manifested in the banning, on 22 August 1988, of the End Conscription Campaign. ${ }^{88}$ This did not stop the tendency and by the time the referendum of 1992 had been held, the Citizen Force was in serious trouble and even those refusing to report for their initial national service were becoming 
significant in numbers. The government itself was no longer extolling the virtues of military service, as De Klerk had unseated the ruling "securocrats". The militarisation of white society had become badly frayed and now its fragile fabric was being ripped apart.

\section{Aftermath in a Democratic South Africa}

With the advent of democracy in 1994, following hard on the heels of the cessation of conscription in 1993, thousands of white South African men found themselves suddenly released from further "camps". For most, it was an indescribable relief. I have yet to find a former conscript who will claim to have enjoyed "township duty", whilst many attest to great nostalgia regarding "border duty".

Yet with democracy came a growing lawlessness accompanied by a seeming paralysis on the part of the authorities to stop it. To those who had served their time in the old SADF, human rights had never extended to criminals. It was almost impossible for such former soldiers to understand or even merely accept that people who perpetrated crimes of violence were not handled as they themselves had been trained to handle those termed "terrorists". In any case, for many whites their forced employment on "township duty" had made them view blacks as "the enemy", and criminal acts by blacks were now often seen as the continuation of a war of terror against whites.

The absence of decisive action by the authorities, often excused on the grounds of bowing to the Constitution, is foreign to the military culture of which most whites had been a part. So too, is an apparent lack of order and structure in the life of society, particularly with regard to law enforcement. In a segment of society as highly militarised as were the whites it is therefore hardly surprising that there is a disillusionment in the face of violent crime which seems to be spiralling out of conrol, criminals who flaunt the law with impunity and the ostensible emphasis on the human rights of criminals rather that those of victims. If this has indeed contributed in some way to the reluctance and cynicism on the parts of some whites to wholeheartedly embrace the process of integration and transformation taking place in the country, then that reluctance and cynicism is perhaps understandable. 